\title{
English Learning with Powtoon Animation Video
}

\author{
Megawati N.M.S \\ English Language Education/ Faculty of Language and Art Ganesha University of Education, Singarja Indonesia \\ Email: sinarmegawati2016@gmail.com
}

\author{
A R T I C L E I N F O \\ Article history: \\ 1 Maret 2020 Received in \\ revised form \\ 30 Maret 2020 \\ Accepted 11 April 2020 \\ Available online 15 \\ Mei 2020

\section{Kata Kunci:} \\ Vedio Animasi PowToon, \\ Bahasa Ingris \\ Keywords: \\ PowToon, \\ Animation Video, English
}

\begin{abstract}
A B S T R A K
Penggunaan media teknologi untuk mengajar di sekolah dasar sangat dibutuhkan. Dalam pengajaran sehari-hari, guru jarang menggunakan teknologi berbasis media. Ini terjadi karena cukup sulit menemukan media yang sesuai dengan silabus. Oleh karena itu, tujuan dari penelitian ini adalah untuk mengembangkan Video Animasi PowToon pada siswa kelas lima SD. Penelitian ini menggunakan Desain dan Pengembangan sebagai metode dengan model ADDIE sebagai prosedur penelitian. Penelitian ini menjawab pertanyaan penelitian terkait pengembangan produk. Beberapa langkah dilakukan untuk mengembangkan produk. Dalam mengembangkan produk, diperlukan analisis, merancang cetak biru, meminta penilaian ahli sebelum produk dikembangkan, dievaluasi dan direvisi produk. Hasil penelitian ini dikategorikan sebagai media unggulan berdasarkan rubrik penilaian pakar. Jadi dapat dikatakan bahwa, media PowToon ini efektif diterapkan di sekolah dasar, hal ini secara langsung akan mampu memperkaya media teknologi yang ada di Sekolah dasar yang berkaitan dengan pelajaran bahasa Ingris.
\end{abstract}

\begin{abstract}
A B S T R A C T
The use of technology media for teaching young learners was really needed. In daily teaching, teacher rarely use the technology based on media. This happened because it was quite difficult to find the media which was appropriate with the syllabus. Therefore, the aim of this research was to develop PowToon Animation Video on fifth grade students of SD N 3 Banjar Jawa. This research used Design and Development as the method with ADDIE model as the research procedures. This research answered the research questions related to the development of the product. Some steps were conducted to develop the product. In developing the product, it needed analysis, designed the blueprint, asked for expert judgments before the product was developed, evaluated and revised the product. The result of this research was categorized as the best media based on the expert judgment rubrics. So it could be said that PowToon media was effective applied in elementary school, this would directly able to enrich the existing media technology in learning English..
\end{abstract}

\section{Introduction}

Nowadays, English subject have been learnt from the early age. According to Aqli, Padmadewi, Suarnajaya (2013) in Indonesia, The English subject has been taught from kindergarten to university level. This phenomenon shows that enthusiastic people to learn English is really big. But students from kindergarten until university students are not the same. Because they have different characteristics between young learners and adult learners. Teaching young learners is crucial. Teaching young learners is quite difficult because of young learners' characteristics. Cameron (2001) states there are several things that differentiate young learners and adult learners. Young learners tend to hunt the teacher's attention meanwhile adult learners will focus on the knowledge. If young learners think the task is too hard to be solved they will really easy to lose interest in learning. That is why the teacher is needed to make sure that young learners will not lose interest easily when the learning process begins. Therefore, in teaching young learner need more strategies in order to make them enjoy the learning process.

The usage of media in teaching and learning process can be a helper for the teacher in teaching young learners. According to Sudjana \& Rivai (2013) media in teaching is needed to make the teaching and learning process more attractive, it also helps the students to understand the material that has been taught. Therefore, the usage of media in teaching young learners is really needed. The media that can be used are conventional media or technology media. The importance of learning media was stated in many researches. One of them was conducted by Suprianti, Mahayanti, Kusuma and Wijayanti (2018). In that research discussed about the development of flashcards and its manual book for teaching English in three elementary schools in Buleleng Regency. In the preliminary observation found that teachers commonly teach vocabularies by giving the list of vocabularies and 
ask the students to memorize the words. But the teachers rarely involved the media such as flashcard in teaching and learning process. Meanwhile teaching vocabularies by using the media that can show the picture was really needed, it can help the students easily to memorize the vocabularies because there was the picture to illustrate the meaning of the word. Based on that, the aims of that research were to develop flashcard and manual book for teaching students in grade sixth and also the quality of the media. And based on the expert judgments the flashcard and manual book categorized as the excellent media for teaching young learners. Therefore, the usage of media in teaching young learners was really needed.

In choosing the type of media, the teacher needs to think which one is appropriate with the students. The students nowadays categorize as Z generation because they were born after 1995. They born in the development of technologies were really wide. $\mathrm{Z}$ generation born in a situation that almost all the activities involve the technology in it. They tend to PC recorder rather than take note. The usage of technology in their activities cannot be avoided. They can use technology in their social life; it will not close the possibility to use technology in the teaching and learning process. The motivation of the students will increase if the teacher involves the technology in the teaching and learning process. According to Mayer (2001) the combination of multimedia such as image, sound and text into one platform will state the message more effectively. Because of that the researcher tries to make the media that can combine the image, sound and text as the learning media. The media which is really appropriate is an animation video. The animation video is the video that combines the image, sound, text and also character into one platform. There is web-based animation software that can be the platform to make animation video for learning English, known as PowToon. This software was founded in 2012. According to Nanni (2015) PowToon is a good potential technology for teaching language. PowToon animation video is a great video and eye-catching. Of course it will attract the students' attention. PowToon is a web-based animation software. It is like the power point presentation Impress, or even Prezi, the creator can add the text, picture, video and also the animations in one slide. This software allows the creator to make the animation in the form of presentation and the outcome of this web-based animation is the video. The video can be uploaded in YouTube, so it is really easy to watch the video letter on, but there will be PowToon watermark if the account is not premium (Pais M. H. R, Nogués F. P, Muñoz B. R , 2017). By using PowToon, the presentation will be more eyes catching. Bahtra.edu (2015) states there are several advantages of PowToon; (1) it is interactive; (2) it covers all aspects of skill; (3) it is practically used; (4) it is collaborative, (5) it can be used in big group of students; (6) it is more various; (7) it can motivate students in learning. Many studies already state that PowToon is a good software to make the animation video for teaching many subjects especially English. By using PowToon animation video, the students learn in an enjoyable way.

Therefore, the researcher has done a preliminary research in order to know the usage of technology in the teaching and learning process in SD N 3 Banjar Jawa. Preliminary research was done through observation, interview and questionnaire for the $5^{\text {th }}$ grade students in that school. Based on the preliminary research find that choosing the appropriate media for teaching was not easy. The teacher was hard to find the appropriate media witch is matched with the syllabus for teaching and learning English. And the teacher had the limited ability to make the media and also not really familiar in making the media based on technology. Therefore, the researcher is needed to do the research that focuses on developing PowToon animation video. The PowToon animation video made in the form of game, it based on the need analysis of the teacher. And it was adjusted with the needs of the teacher in the teaching and learning process, especially for fifth grade students at Elementary School. The grade fifth have been chosen for the subject of this research because of the other researchers still working in the same research but in different grade such as 1, 2, 3, 4 and 6. This research only focuses on developing the PowToon Animation Video as the learning media for fifth grade in Buleleng Regency. Based on the background above, there research question in this study was how did the development of PowToon Animation Video as a learning media for $5^{\text {th }}$ grade students in SD N 3 Banjar Jawa. To answer the question, the researcher use ADDIE model as the procedures of this study.

Many researches have been discussed about media ICT and also PowToon. Most of them discuss about the effectiveness of media ICT and PowToon for the language skill of the students. For example; the research that is conducted by Syafitri, Asib and Sumardi in 2018, shows that PowToon as the media for teaching can help the students in develop the speaking ability especially pronunciation in senior high school. And the other research that is also related with PowToon has been done by Yuniari. In her study the usage of PowToon animation video as the media to develop the writing achievement of the students in Dwijendra University. Those researches focus on the skill of learning language. But none of them discuss about integrated skill and also focus on young learners. Meanwhile in teaching English teacher cannot focus only on one skill, but all of them should combine. Based on that the researcher is really needed to this research that not only focuses on one skill but it is integrated. And more than that this research is developed the media for teaching young learners while the other research is rarely in doing that.

\section{Method}


This study used Design and Development as the method. DnD is a methodology that focuses on designing, creating and evaluating. This research has the aim to produce something, it can be instructional and noninstructional products and tools and new or enhanced models (Richey \& Klein, 2014). And ADDIE model as the research procedures in this study. The steps of ADDIE model, according to Romiszowski in Tegeh, Jampel \& Pudjawan (2014) are analyze Design, Development, implementation and evaluation. This article was a part of the study that had two purposes. The first purpose was to develop PowToon Animation Video and the second one was to know the quality of PowToon Animation Video. Therefore, this article only focuses on the development of PowToon Animation Video as English learning media for $5^{\text {th }}$ grade students in SD N 3 Banjar Jawa. The procedures of ADDIE models that were used to develop the video were analyzing, designing and developing.The first one was analysis. To know the needs of the students and also the teacher, to know the topic and also the scope of the material in the syllabus the analysis was conducted. The second one was design. In this step, the blueprint for the media was designed. The blueprint was made based on the material from the need analysis. The third one was developed the media. In this step the developed the media was started. After the media was done to be developed, the expert judgment after and before revision were conducted.

\section{Results and Discussion}

The development of the product was discussed in this step. There were three steps that was conducted namely analysis, design and development.

\section{Analyze}

There were several things that analyzed by the researcher in this step. There were the interview guides, the document study (syllabus) and also the students' questionnaire. Those instruments were analyzed in order to know the need analysis of the teacher and also the students. And the result of teacher's Interviews were first the teacher can use laptop but not really master it, second the teacher was difficult to find the media in the internet which is appropriate with the syllabus, third the teacher needed the media which was appropriate with the syllabus. Fourth the media that should be developed in the form of video game to make various type of media.Then the result of students' questionnaire were from 28 students in the class $100 \%$ said that they like to learn English. For the next point about the way the teacher teaches in the class, $76.70 \%$ stated that the teacher always monotonous in teaching and $23.30 \%$ said it was innovative. For the Point about the usage of media was such as laptop or mobile phones in the classroom $60 \%$ students stated that the teacher did not use any media in teaching and $40 \%$ stated that the usage of media was rarely. For the last point about the attractiveness in learning, $70 \%$ stated they like to learn by using the technology media, $6.7 \%$ for answering question, $20 \%$ discussion section and $3 \%$ chose the game. From those result can be said that the students were like to learn by using the media, the students felt motivated if the teacher involved the media in teaching and learning process, but the teacher rarely or almost never to use the media in the classroom. The students wanted to learn with the media in the classroom or outside the classroom. Then the result of document study was the topic of the media that was developed into the media. There were clothes, animals, food and drink, parts of body and public places. The document study was the next step after the questionnaire contributed. The document that was used by the researcher was the syllabus. The syllabus of grade $5^{\text {th }}$ in SD N 3 Banjar Jawa. Then the result of syllabus analysis was, there were 5 topics that used in the media were clothes, animals, food and drink, parts of body and public places.

\section{Design}

The design step was the next step after analyze. In this steps the researcher designing the blueprint for developing PowToon Animation Video. The blueprint consisted of the basic competences, the topic the type of the game. The Blueprint can be seen as follows.

Table 1. The blueprint of the media.

\begin{tabular}{lll}
\hline Basic competence & Topic & Type \\
\hline Listen to words about clothes. & & \\
Reading comprehends the contents of the text & Clothes & Multiple choices.
\end{tabular}

/ dialogue relating to clothes.

Listen to statements, orders relating to animals.

Reading. Understand the text content related Animals Guessing game and complete the to animals. dialogue 
Listen to statements, orders relating to drinks

and food.

Reading.

Food and drink

True/ False and essay.

Understands the contents of the text about of

food and drink.

Listen to words related to human body parts.

Listen to commands relating to parts of the Parts of body Simon says and scrambles letters. human body

Listen to the names of public places.

Listen to public place functions.

Read

Public Places

Guessing game.

Understand the contents of the text about

public places.

Based on the blueprint above can be known that there were five topics that developed into PowToon Animation Video. There were clothes, animals, food and drink, parts of body and public places.

\section{Develop}

The next step after designing was developing the video. In developing PowToon Animation Video, the researcher conducted some steps. There was developing, expert judgment material before and after revision and expert judgment media before and after revision and final product. The first one was developed the video. The video was developed based on the syllabus analysis that was done in analysis steps. There were 5 topics that needed to be developed in the form of PowToon Animation Video. The second one was expert judgment material. After PowToon Animation Video was developed the expert judgment of the material held. The first expert was Dr. I G A Lokita Purnamika Utami, S.Pd, M.Pd and the second expert was G A P Suprianti S.Pd, M.Pd. The evaluation sheet that used was related with the rubric used by Mahayanti in 2017. It was used to determine the quality of PowToon Animation Video. The purpose of expert judgment material was to know whether the video already appropriate with the syllabus and also whether there were problems in material aspect. The result of expert judgment was analyzed by using Nurkancana and Sunartana theory. The table can be seen as follows

Table 2. The Categories in Rating PowToon Video

\begin{tabular}{cc}
\hline Score & Creteria \\
\hline $\mathrm{X} \geq \mathrm{Mi}+1.5 \mathrm{Sdi}$ & Excellent \\
$\mathrm{Mi}+0.5 \mathrm{Sdi} \leq \mathrm{X}<\mathrm{Mi}+1.5 \mathrm{Sdi}$ & Good \\
$\mathrm{Mi}-0.5 \mathrm{Sdi} \leq \mathrm{X}<\mathrm{Mi}+0.5 \mathrm{Sdi}$ & Average \\
$\mathrm{Mi}-1.5 \mathrm{Sdi} \leq \mathrm{X}<\mathrm{Mi}-0.5 \mathrm{Sdi}$ & Below average \\
$\mathrm{X}<\mathrm{Mi}-1.5 \mathrm{Sdi}$ & Poor \\
\hline
\end{tabular}

(Nurkancana \& Sunartana in Mahayanti(2017))

Notes:

$\mathrm{Mi}=1 / 2($ Score Max + Score Min $)$

$\mathrm{Sdi}=1 / 3(\mathrm{Mi})$

$\mathrm{Mi}=$ the Ideal Mean

$\mathrm{Sdi}=$ the Standard of Deviation

$\mathrm{X}=$ The Score of the teacher

And the result of expert judgments material before revision was the video categorize as a good media and also excellent media. The first expert gave 64 points for the media and it categorized as good media. For the second expert gave 71 points for the media and it categorized as an excellent media. The experts also suggested revising some points related with the material of the video. The next was revised the video. The experts suggested to revised in the form of grammar and also punctuation. The researcher revised the video with all of the suggestions from the experts. 
Table 3. The revision in the form of grammar.

Before Revision
Please answer the questions with the complete Revision
answer. Look at the example bellow.
Look at the following example.

Based on the table can be seen that the slides which were had grammar problem. The first one the sentence "Look at the example bellow" become "Look at the following example. For the second slide was about the article. The word "milk" became "the milk". The revisions were done in the form of grammar mistake, the next was the revision in the form of punctuation mistake.

Table 4. Revision in the form of punctuation

\begin{tabular}{lll}
\hline Before revision & After revision \\
\hline She brings the cookies & She brings the cookies. \\
\hline SHE BRANIS & THE COOKIES & SHE BRINGS \\
\hline
\end{tabular}

Based on the table above, it can be seen that the slide missed the punctuation in the end of the sentence. Therefore, the revision process was held. When the revision process already done, there were expert judgments after revision. The result of expert judgment analyzed by using Nurakncana and Sunartana theory. Then the result was PowToon Animation Video was categorized as an excellent media. it meant PowToon Animation Video was improved after revision process. After the process of expert judgment material, the next was expert judgment in the form of media. There was one expert of the media who judged the PowToon Animation Video. The expert was I Nyoman Laba Jayanta, S.Pd, M.Pd. The evaluation sheet that used is related with the rubric used by Rifai (2015). After the process of expert judgment media, the expert suggested some criteria which were needed to be revised in the PowToon Animation Video. There were about the quality of the image, the size of the image, the size of text balloon. The expert suggested that the size of text balloon should minimize because it was too big. The result of expert judgment media before revision was, PowToon Animation Video categorized as a good media. It was analyzed by using Nurkancana and sunarta theory. After the process of revision, the expert judgment held again. The purpose was to know whether the PowToon Animation Video improved or not. The expert gave the better score after the revision. It meant the media was improved. Then PowToon Animation Video was categorized as an excellent media. The final product of PowToon Animation Video can be developed after the process of expert judgments after revision. The final product detail can be seen below.

Table 5. The Final Prototype Product of PowToon Animation Video 


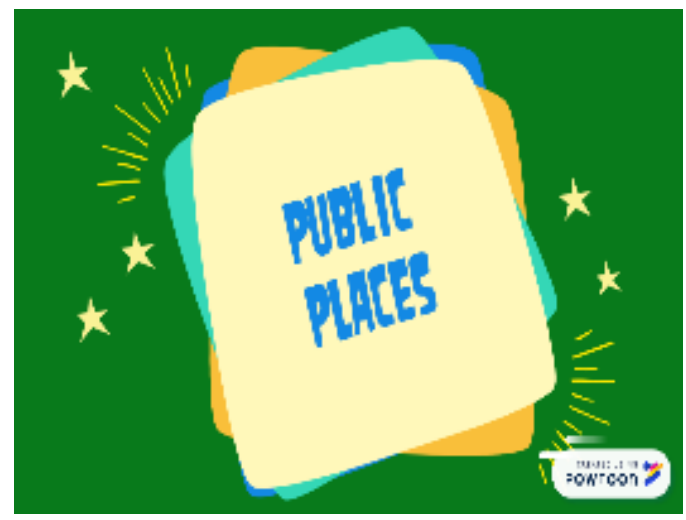

Cover of PowToon Animation Video.

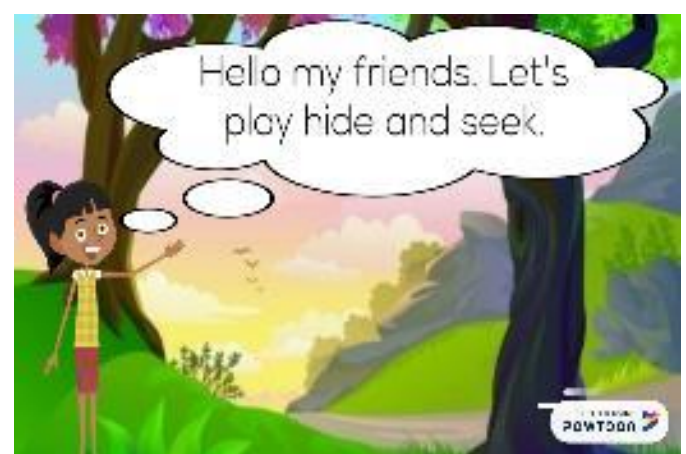

The Introduction of PowToon Animation Video.

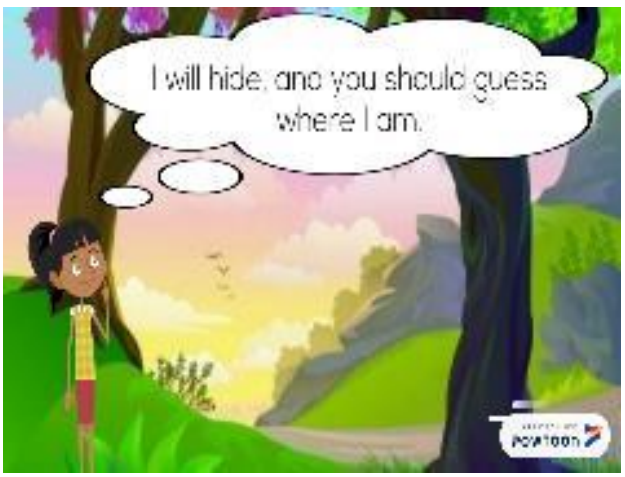

The instruction for the game of PowToon Animation Video.

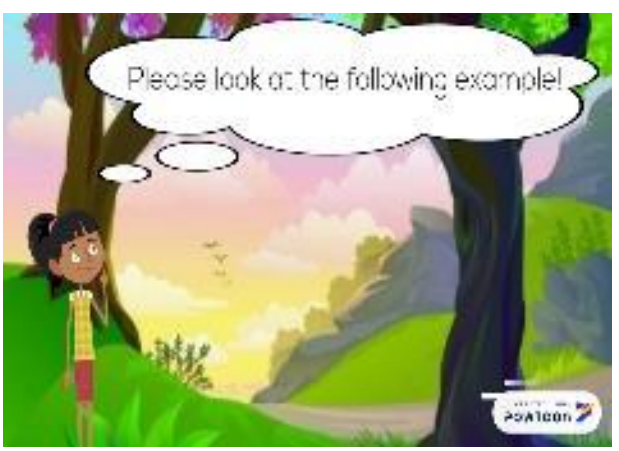

The instruction for the game of PowToon Animation Video. 


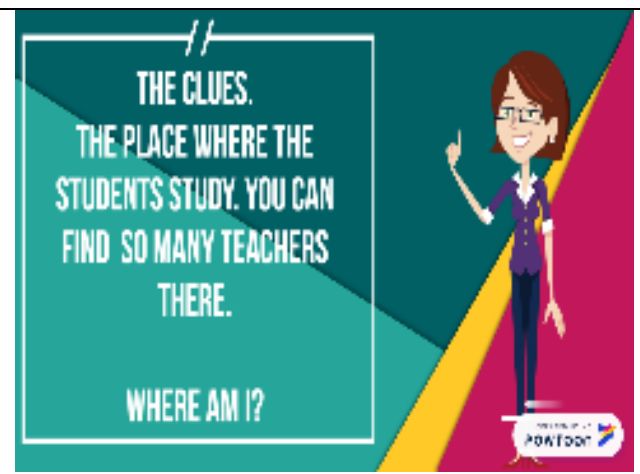

The example of game in PowToon Animation Video.

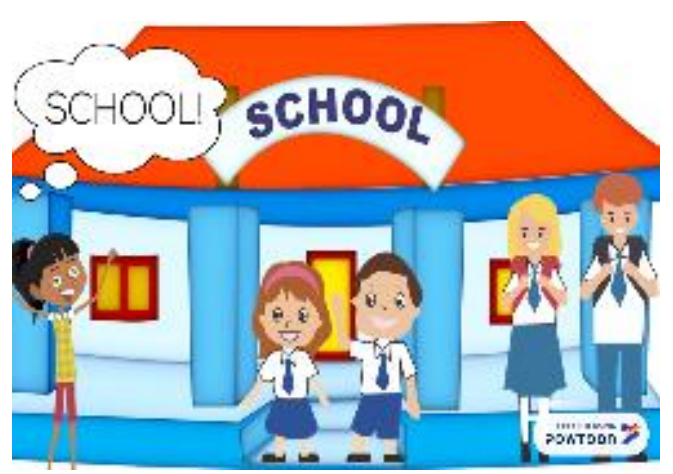

The example of answer in PowToon Animation Video.

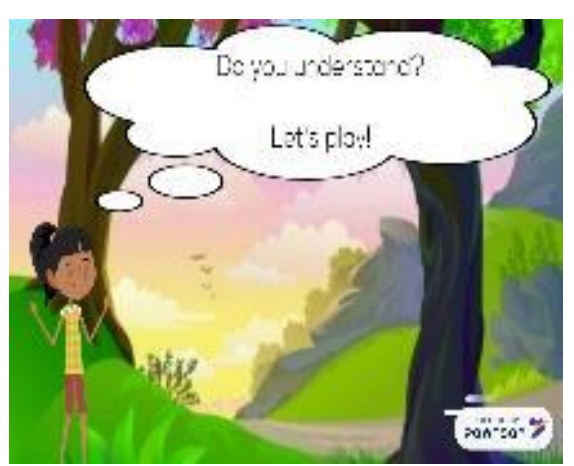

The question before the game begins.

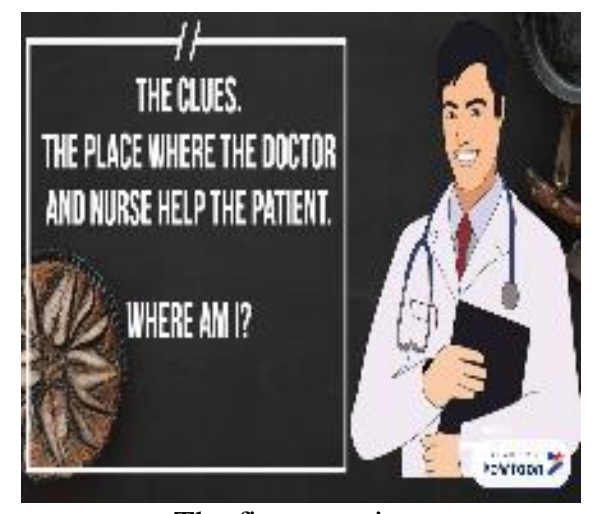

The first question. 


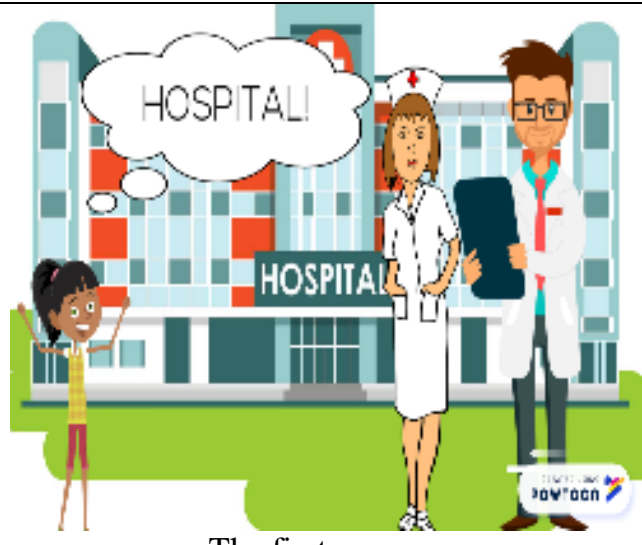

The first answer.

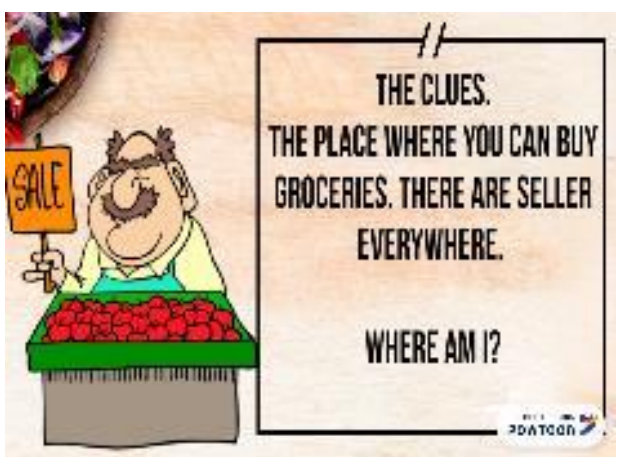

The second question.

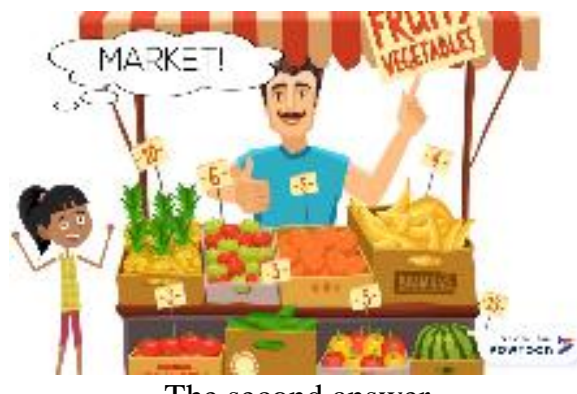

The second answer.

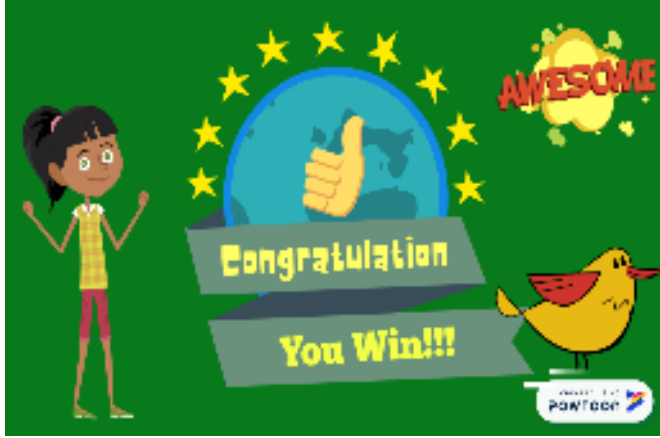

The closing cover.

Based on the process of development above can be conclude that the process of developing PowToon Animation Video as a learning media needed some steps. The first step was conducting analysis. The things that should analyze were the needs of teacher, the needs of the students and also the syllabus. The second one was designing. The blueprint for every topic was needed and also the final blueprint also needed. And then the next step was developed the media. In developing the media there were some steps also; made the media, expert 
judgment material revision, expert judgment material after revision, then expert judgment media, revision, expert judgment media after revision and the last was final product The PowToon Animation Video can be continued to implementation process.

\section{Discussion}

In discussion the problem which is faced by the researcher explained. This research focuses on developing PowToon Animation Video for $5^{\text {th }}$ grade students in SD N 3 Banjar Jawa. Therefore, in the process to achieve the purpose, the researcher faced many problems. There are some points that can be discussed in the discussion. Based on the preliminary observation. The researcher found that the students in grade $5^{\text {th }}$ more enjoyable when learning by involving the media rather than hearing the explanation from the teacher. This is supported by Harmer (2007) which states that young learners like to learn by see, hear, touch and also interact directly with something rather than just hearing much explanation. It is still related with the first discussion. It is about the students' questionnaire. The students feel more motivated in learning by using the media. This is supported Sudjana \& Rivai (2013) the media in teaching can make the teaching and learning process more attractive, it also helps the students to understand the material that have been taught by the teacher. Afach, Kiwan and Semaan (2018) also support in this point. The usage of technology in education, video presentation tool in particular, made the students easier to understand the concept in learning. And make a good situation in the classroom.

This is also about the result of the questionnaire. The students who categorize as $\mathrm{z}$ generation and also young learners are interested in the usage internet in their social life. Most of the students in grade $5^{\text {th }}$ uses hand phone outside the classroom. That statement was supported by Dewi (2017), states that most of children are interested in internet, television, radio, youtube, or another mobile learning. In developing the PowToon Animation Video, the researcher conducted some revision. The revision in the form of material and also the media. The researcher was done the revision, had the purpose to create a good animation video for learning which appropriate with the syllabus and also had an interesting presentation. This is also supported by Munkiman in Nurseto (2011). The good media should follow the VISUAL principles; easy to be seen, interesting for students, simple and easy to used, reliable or can be accounted valid or make sense and designed systematically. The use of media technology in teaching young learners can be the solution for the teacher. When the teacher was involved the technology media in teaching the students more enthusiastic and focus in the learning process. Above already stated that young learners tend to get bored if the situation in the classroom was happened in monotonous way. Therefore, the usage of PowToon Animation can be the choice for the teacher

\section{Conclusion and Suggestions}

The purpose of this study was to develop PowToon Animation Video for $5^{\text {th }}$ grade students in SD N 3 Banjar Jawa. Based on the purpose of this study, the conclusion of this study can be seen as follows. 1) The PowToon Animation Video was developed based on the syllabus analysis. PowToon Animation Video was developed in the form of game as the need analysis of the teacher. From that analysis was found five topics that should be developed. The topics were; clothes, animals, food and drink, parts of body and public places. 2) PowToon Animation Video was finished to be developed there were expert judgments. The process of expert judgments were happened twice (before and after revision) in the form of material and twice in the form of media (before and after revision). Then the final product was design. And the entire expert already states that the media was an excellent media for $5^{\text {th }}$ grade students in SD N 3 Banjar Jawa. Simply, the process of developing PowToon Animation Video needed the process of analysis the needs of the teacher, needs of the students, and the syllabus. The next need to make the blueprint for all the topic and developing the product with expert judgment.

After need analysis, design the materials, implement, and got students and the teacher response toward the media, the writer gives some suggestions to those who might be benefited to the result of this research. Those suggestions can be proposed as follows: 1) For English Teacher. It is suggested to the English teacher to use the technology media such as video animation for teaching. Because the students more motivated if the usage of video animation involve in the teaching and learning activity. So this animation video can make the students learn English in interesting way. 2) For Other Researchers. It is suggested to the other researcher to do the research in developing media for learning activity. This research only focus on one subject (English) and focus in grade $5^{\text {th }}$. The other researchers suggested developing the learning media based on technology in different field. And also with the various form as well as lengthier in time. 3) For the Institution (Ganesha University of Education). It is suggested for the institution to use the product of this study as additional material in teaching the prospective teachers about the alternative supporting media for elementary school students to motivate students in learning English.

\section{References}


Aqli, Padmadewi, Suarnajaya. (2013). The Practice of English Language Teaching and Learning in. e-Journal Program Pascasarjana Universitas Pendidikan Ganesha, Volume 1.

Bahtraedu. (2015, April 19). Media Pembelajaran Powtoon. Retrieved from http://bahtra12.blogspot.com/ 2015/04/media-pembelajaran-powtoon.html

Cameron, L. (2001). Teaching Languages to Young Learners. Cambridge: Cambridge University Press.

Dewi, P. (2017). Teaching English for Young Learners Through ICTs. ISBN, 978-602-1180-45-7.

Mahayanti, N. W. (2017). Developing CALF (Contextual, Attractive, Logical). International Journal of Language and Literature, Volume 1, Number 2.

Marcelle, G. (2000). Justice and ICTs. Gender.

Mayer, R. E. (2001). Multimedia Learning. UK: Cambridge University Press.

Nanni, A. 2015. Teaching through the use of cloud-Based Nanni, A. 2015. Teaching through the use of cloud-Based animation software. English Language Education in ASIA: Reflections and Directions. P. 1-11.

Nurseto, T. (2011). Membuat Media Pembelajaran Yang Menarik. Jurnal Ekonomi \& Pendidikan, 19-35.

Pais M. H. R, Nogués F. P, Muñoz B. R . (2017). Incorporating Powtoon as a Learning Activity into a Course on Technological Innovations as Didactic Resources for Pedagogy Programs. iJET, Vol. 12, No. 6.

Richey \& Klein . (2014). Design and Development Research. Handbook of Research on Educational Communications and Technology.

Rodriguez F. and Wilson, E. (2000). Are Poor Countries Losing the Information Revolution? :. Washington DC: World Bank: infoDev Working Paper.

Sudjana \& Rivai. (2013). Media Pengajaran. . Bandung: Sinar Baru.

Syafitri, Asib, Sumardi. (2018). An Application of Powtoon as a Digital Medium: Enhancing Students' Pronunciation in Speaking. International Journal of Multicultural and Multireligious Understanding, 2364-5369.

Tegeh, Jampel, \& Pudjawan. (2014). Model Penelitian Pengembangan. Yogyakarta: Graha Ilmu.

Yuniari. (n.d.). The Effect of Using Powtoon Audiovisual Media Upon The Students' Writing Achievement of The Third Semester Students of English Education Department Faculty of Teacher Training and Pedagogy Dwijendra University. Universitas Dwijendra Denpasar. 